\title{
The potential of forest biomass as an energy supply for Canada
}

\author{
by David Paré ${ }^{1,2}$, Pierre Bernier ${ }^{1}$, Evelyne Thiffault ${ }^{1}$ and Brian D. Titus ${ }^{3}$
}

\begin{abstract}
There is a growing interest in using forest biomass as an energy source. The main objectives of this paper are to give some figures and perspectives on Canadian forest biomass supply with respect to Canada's energy demand and to examine the potential of using this feedstock for reducing our greenhouse gas (GHG) emissions. Published estimates of forest biomass supply as harvest residues are reported and discussed. The range of estimates listed here indicates that this source of energy is important but that it is still a fraction of our energy demands. The potential of using this biomass to reduce our GHG emissions is strongly dependent, among other factors, on the technological pathways that are used, with direct heat production and combined heat and power (CHP) ranking amongst the best options available. The relative scarcity of the resource behooves us to use it efficiently.
\end{abstract}

Key words: forest biomass, residue, greenhouse gas, mitigation, energy, sustainable forestry

\section{RÉSUMÉ}

Lutilisation de la biomasse forestière comme source dénergie suscite un intérêt grandissant. Les principaux objectifs de cet article sont de présenter des estimés et des perspectives sur la quantité de biomasse forestière disponible au Canada par rapport à la demande énergétique canadienne et d’examiner le potentiel d'utilisation de cette biomasse pour réduire notre production de gaz à effet de serre (GES). Les estimés publiés sur la quantité de biomasse forestière disponible sous forme de résidus de coupe montrent que cette ressource est importante, mais quelle ne constitue néanmoins qu’une fraction de notre demande énergétique. Le potentiel de réduction de nos émissions de GES par l'utilisation de cette biomasse dépend fortement, entre autres choses, de la voie technologique utilisée. La combustion directe pour la production de chaleur et la production concomitante de chaleur et délectricité (CHP) sont parmi les voies les plus efficaces. La relative rareté de cette ressource nous incite à l'utiliser de façon efficace.

Mots clés : biomasse forestière, résidus, gaz à effet de serre, atténuation, énergie, foresterie durable

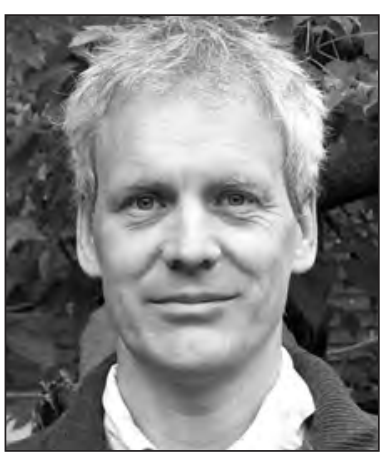

David Paré

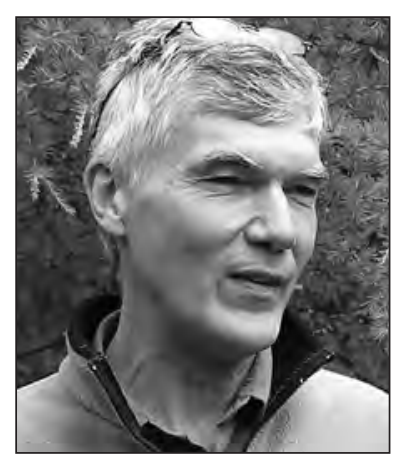

Pierre Bernier

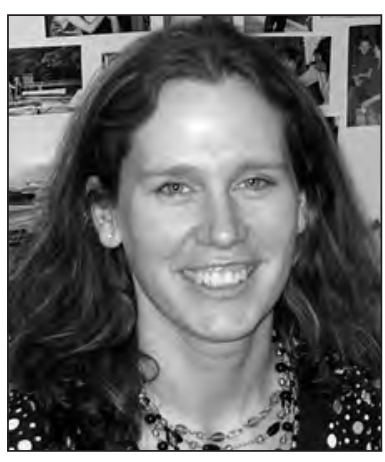

Evelyne Thiffault

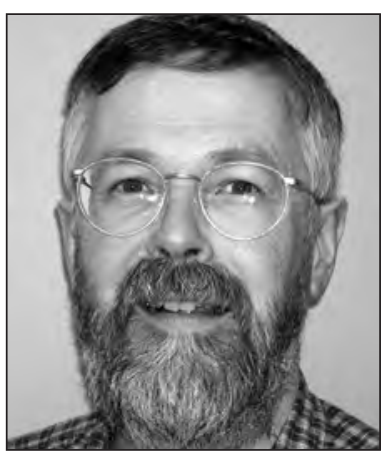

Brian D. Titus

\section{Introduction}

The use of forest biomass as a source of bioproducts, especially energy, has recently been generating much interest in Canada for several reasons. Harvest and sale of biomass and bioproducts is seen as a potential source of revenue for a forest industry experiencing difficult times and looking to diversify its markets. Biomass use for bioenergy provides an opportunity for reducing fossil fuel emissions. Also, biomass

is a renewable, locally available, and often locally abundant source of energy. Canada is blessed with a high forest bioenergy potential because of its small population (34 M) relative to its large managed forest ( $>2$ million $\mathrm{km}^{2}$ ) and timber supply (250 $\mathrm{Mm}^{3} \mathrm{y}^{-1}$ annual allowable cut). The potential for forest bioenergy to meet per capita energy requirements is therefore high relative to other nations-Canada harvests about 8 $\mathrm{m}^{3}$ of wood per capita per year, the third-highest per capita

\footnotetext{
${ }^{1}$ Natural Resources Canada, Canadian Forest Service, Laurentian Forestry Centre, 1055 du P.E.P.S., P.O. Box 10380, Stn. Sainte-Foy, Quebec, Québec G1V 4C7.

${ }^{2}$ Corresponding author. E-mail: dpare@nrcan.gc.ca

${ }^{3}$ Natural Resources Canada, Canadian Forest Service, Pacific Forestry Centre, 506 West Burnside Rd., Victoria, British Columbia V8Z 1 M5.
} 
production after Finland $\left(14 \mathrm{~m}^{3}\right)$ and Sweden $\left(9 \mathrm{~m}^{3}\right)$, and far ahead of other large producers such as the U.S. and Brazil (2 $\mathrm{m}^{3}$ each), and Russia and the Democratic Republic of the Congo ( $1 \mathrm{~m}^{3}$ each) (FAO 2007). But is this enough to meet our demands for both energy and forest products-including emerging bioproducts? The objectives of this paper are to explore both the potential for Canada's forests to contribute to domestic energy demand and consequently, how the use of forest biomass could help reduce our greenhouse gas emissions. The focus is on managed forests and does not include perspectives on energy plantations, which are still largely at an experimental stage in Canada.

\section{Estimating Forest Biomass Supply}

Within a bioenergy context, forest biomass is any biological material that comes from trees. The majority of the biomass harvested in Canada is roundwood for production of conventional forest products, and it is the residues from this production that are currently most readily available as a source of energy.

There are three main sources of forest residues (Röser et al. 2008): (i) primary residues are by-products of conventional forest management, such as biomass from thinnings, harvesting residues, non-commercial species, and-in some jurisdictions-even stumps; (ii) secondary residues are by-products of industrial processes, such as bark, sawdust and black liquor and (iii) tertiary residues are by-products of demolition, construction and packaging processes. Estimates for secondary residues at mills are relatively accurate. However, this feedstock is already fully utilized in forest products (pulp, chipboard) or as a source of energy in mills. Municipalities are also increasingly interested in generating value from tertiary residues but supplies are limited, although largely underutilized at the moment. The potential for an increase in forest bioenergy production under current market conditions therefore largely depends on the increased recovery of primary residues from forest harvesting. However, more or other sources of forest biomass may become available under favourable economic conditions. For example, biomass from stand rehabilitation operations and salvage logging after natural disturbances could be used as feedstock; intensified forest management could increase the supply of biomass from thinning or increase the uncut proportion of AAC, which could allow roundwood to be diverted to bioenergy use; and an increase in forest harvesting for expanding markets would increase residue production along the entire value chain.

While forest harvesting residues are the largest stable potential source of bioenergy for Canada, estimating its level of supply is complex. Several estimates of the Canadian potential supply of forest harvesting residues are available at a national scale. Some of these estimates are listed in Fig. 1 together with an estimate of the volume of harvested roundwood. The estimated volumes provided by the studies listed in Fig. 1 range from 30 to $66 \mathrm{~m}^{3} \mathrm{ha}^{-1}$ $\mathrm{yr}^{-1}$. It is possible to calculate a logging residue ratio (Smeets and Faaij 2007). The operationally derived residue estimates of Sidders et al. (2008) and estimates of roundwood harvested can be used to calculate a logging residue ratio (Smeets and Faaij 2007) of 19\% for roadside residues to roundwood, and $24 \%$ for mill plus roadside residue to roundwood.

Most inventories generate a maximum theoretical estimate of available forest harvesting residues. In practical terms, however, estimates of available residues need to factor in the operational feasibility of residue recovery from harvesting sites, the economic feasibility of this recovery, and the amount that needs to be left on site to maintain ecosystem functions (Smeets and Faaij 2007). These three latter factors overlap in defining the opportunities for harvesting residue recovery. For example, Ralevic et al. (2010) found that it was technically possible to recover only $25 \%$ to $59 \%$ of the total available volume of harvesting residues on two sites in northern Ontario. The amount of harvesting residue that can be cost-effectively recovered will also depend on a range of economic factors (e.g., Grushecky et al. 2007).

The operational and economic factors controlling recovery rate of residues will invariably change with the evolution of equipment and forest management systems, and with market values, subsidies and government policies. However, the biophysical resources that underpin forest growth (e.g., topography, climate, bedrock and surficial geology, soils, hydrology) interact with species requirements to define an ecologically sustainable level of harvesting residue removal. Unlike operational and economic constraints, the biophysical resources (and resultant ecosystems) are relatively constant over the time frame of forest management cycles and therefore define the baseline opportunity for harvesting residue removals, including operational recovery. The operational and economic factors can then be applied to this baseline opportunity to refine estimates for an inventory upon which a forest bioenergy sector can be developed in Canada.

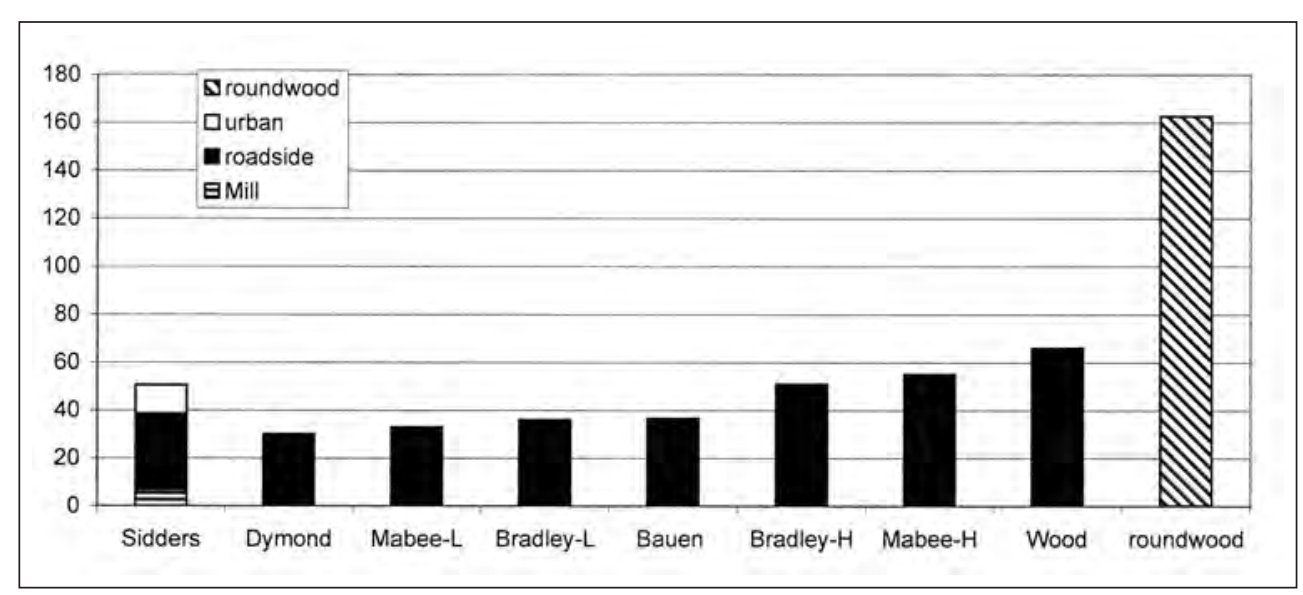

Fig. 1. Comparison of estimates of available volumes of forest biomass residues ( $\mathrm{Mm}^{3} / \mathrm{yr}$ ) with harvested roundwood volume in 2007 (NRCan 2009). (Sidders: Sidders et al. 2008; Dymond: Dymond et al. 2010; Bauen: Bauen et al. 2004; Mabee: Mabee et al. 2006; Bradley: Bradley 2009; Wood: Wood and Layzell 2003; L for low estimate and $\mathrm{H}$ for high estimate). 
Forest harvesting residue inventories must therefore take ecological factors into consideration. Sites can be excluded from tree or residue harvesting because of environmental concerns such as soils with excessive drainage, low organic matter content or low nutrient supply, or where there are biodiversity or conservation issues (Hesselink 2010, Thiffault et al. 2010). These factors can be incorporated into guidelines and regulations governing harvesting residues recovery and hence some jurisdictions define a proportion of harvesting residue that should be retained (e.g., 20\% in Sweden [Skogsstyrelsen 2008] and 30\% in Finland [Koistinen and Äijälä 2005]) and also sensitive sites where residues should not be removed (e.g., New Brunswick; Government of New Brunswick 2008). On-site harvesting residue retention assumptions in inventories can range from $0 \%$ to $100 \%$ (Titus et al. 2009) but generally a single figure is applied at a jurisdictional (usually national) level for inventory estimates. However, use of spatially explicit assumptions of residue retention rates should improve the accuracy of biomass inventories. In the only study of its kind so far, a spatially explicit projection of forest inventory was combined with spatially explicit site suitability factors (soil properties) to estimate the environmentally sustainable harvesting residue potential for Europe (European Environment Agency 2006). When summed over the EU, inclusion of site suitability factors reduced the total potential inventory by $40 \%$. A reduction of $50 \%$ was used in the estimate of Dymond et al. (2010) presented in Fig. 1.

As mentioned earlier, several other sources of biomass could be readily available in addition to forest harvest residues. Residues from non-commercial species felled as part of silvicultural operations, from dead wood, and from parts of logs unfit for other industrial processes, are potentially available but are difficult to evaluate. Salvaged wood from areas affected by stand-replacing natural disturbances is also potentially available, and Dymond et al. (2010) estimated that there is twice as much available as from clearcut harvest residues. However, local availability of disturbance-generated biomass is unpredictable and physical access to disturbed sites can also be problematic. By contrast, supplies of harvesting and industrial residues are more reliable as sources of bioenergy feedstock, with year-to-year variation depending largely on harvesting rates.

It may also be possible to produce more forest biomass of different types. Any increase in forest productivity through the intensification of forest management that led to increased harvesting and processing would generate a proportional increase in residue availability, an option that is often overlooked. For example, the Atlantic Provinces Economic Council (2003) stated that it would be relatively easy to double the forest productivity of public lands in New Brunswick within 35 years. An increase in forest plantations, given adequate deployment, could supply more biomass without necessarily harming the environment (reviewed in Paquette and Messier 2010). Also, supply increases due to afforestation and use of dedicated bioenergy crops are other options that could increase the supply of forest biomass, but expansion of these sources creates other challenges.

In conclusion, harvesting residues are intuitively the largest most readily accessible source of forest biomass for energy production, but availability is certainly smaller than the theoretical potential once ecological, operational and eco- nomic factors are taken into consideration. This difference between theoretical potential and available biomass will undoubtedly converge over time with the development of technologies for improving operational efficiency and with the generation of knowledge on biomass requirements to support ecosystem processes and the subsequent implementation of intensive harvesting regulations. The figures presented here should therefore not be considered as precise and definitive estimates of forest biomass availability.

\section{How Much Primary Energy Can the Forest Supply in Canada?}

Primary energy is energy in its natural form (such as unprocessed coal, oil and water) before it is converted into an end-use fuel or form of energy (e.g., processed coal, gasoline or diesel, and hydroelectricity). In 2005, 12.25 exa joules ( $10^{18}$ joules, or $\mathrm{Ej}$ ) of primary energy were used in Canada (NRCan 2006). Bioenergy accounted for about $5 \%$ of the total (0.59 $\mathrm{Ej}$ ), of which the vast majority was produced and used by the forest industry (Table 1). In fact, the increased use of black liquor and wood residues by the forest industry as lower-cost energy sources led to a $6 \%$ net reduction in GHG production in the forestry sector between 1980 and 2005 despite a $21 \%$ increase in energy use (NRCan 2009).

The estimated potential bioenergy supply from Canada's forests is small compared with total national energy consump-

Table 1. Breakdown of total primary energy use by sources in Canada in 2005 (NRCan 2006)

\begin{tabular}{lcc}
\hline & Energy (Ej) & \% of total \\
\hline Total & 12.25 & 100 \\
Petroleum & 4.59 & 37.5 \\
Natural gas & 3.44 & 28.1 \\
Coal & 1.22 & 10.0 \\
Nuclear & 1.04 & 8.5 \\
Hydro & 1.20 & 9.8 \\
Biomass $\quad 0.59$ & 4.8 \\
$\quad$ Industrial biomass residue & & \\
$\quad$ (pulp and paper) & 0.46 & 3.9 \\
$\quad$ Residential fuel wood & 0.11 & 0.9 \\
\hline
\end{tabular}

tion (Fig. 2). Bioenergy production from all urban and roadside harvest residues would supply only an additional $5 \%$ of what is produced from fossil fuels, or $4 \%$ of the total energy used in Canada. If all the roundwood production of Canada was added to this estimate (Fig. 1), forests would still only contribute $18 \%$ to the total national energy consumption (Fig. 3).

\section{The Importance of Technological Pathways}

The potential contribution of forest bioenergy to meeting Canada's energy needs presented in the figures mentioned above are still over-optimistic because in reality one unit of energy production is not equivalent to one unit of energy consumption since the efficiency of the conversion of wood biomass into a usable energy form is dependent on the technology pathways used. This is well-illustrated by efficiency rates for energy conversion (compiled by the Manomet Center for Conservation Sciences 2010)-the efficiency of converting green wood to electrical power is only $25 \%$, the heat 


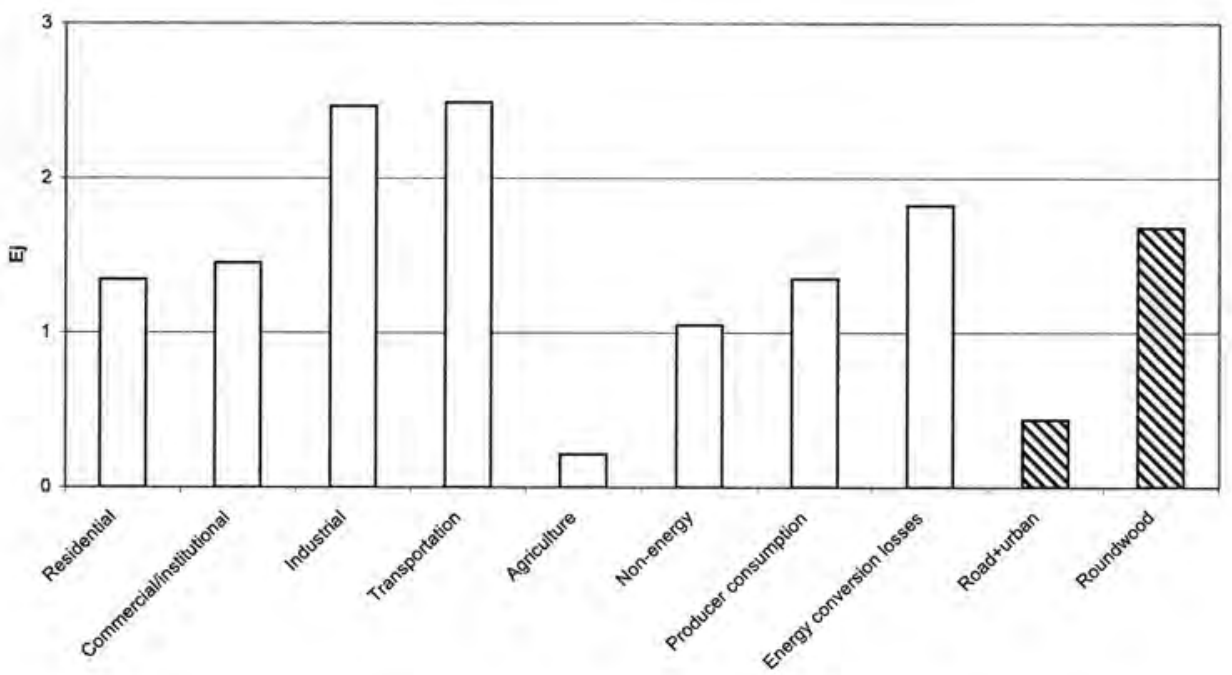

Fig. 2. Comparison between annual energy use in Canada ( $\mathrm{Ej}$ ) in 2007 (OEE 2010) and the amount of energy (hatched bars) in roadside and urban forest residues (Sidders et al. 2008) and in roundwood (NRCan 2009), assuming 0.58 oven dry T per $\mathrm{m}^{3}$ green wood (FAO 1998) and an energy content of 18 Gj/odt (Ralevic et al. 2008).

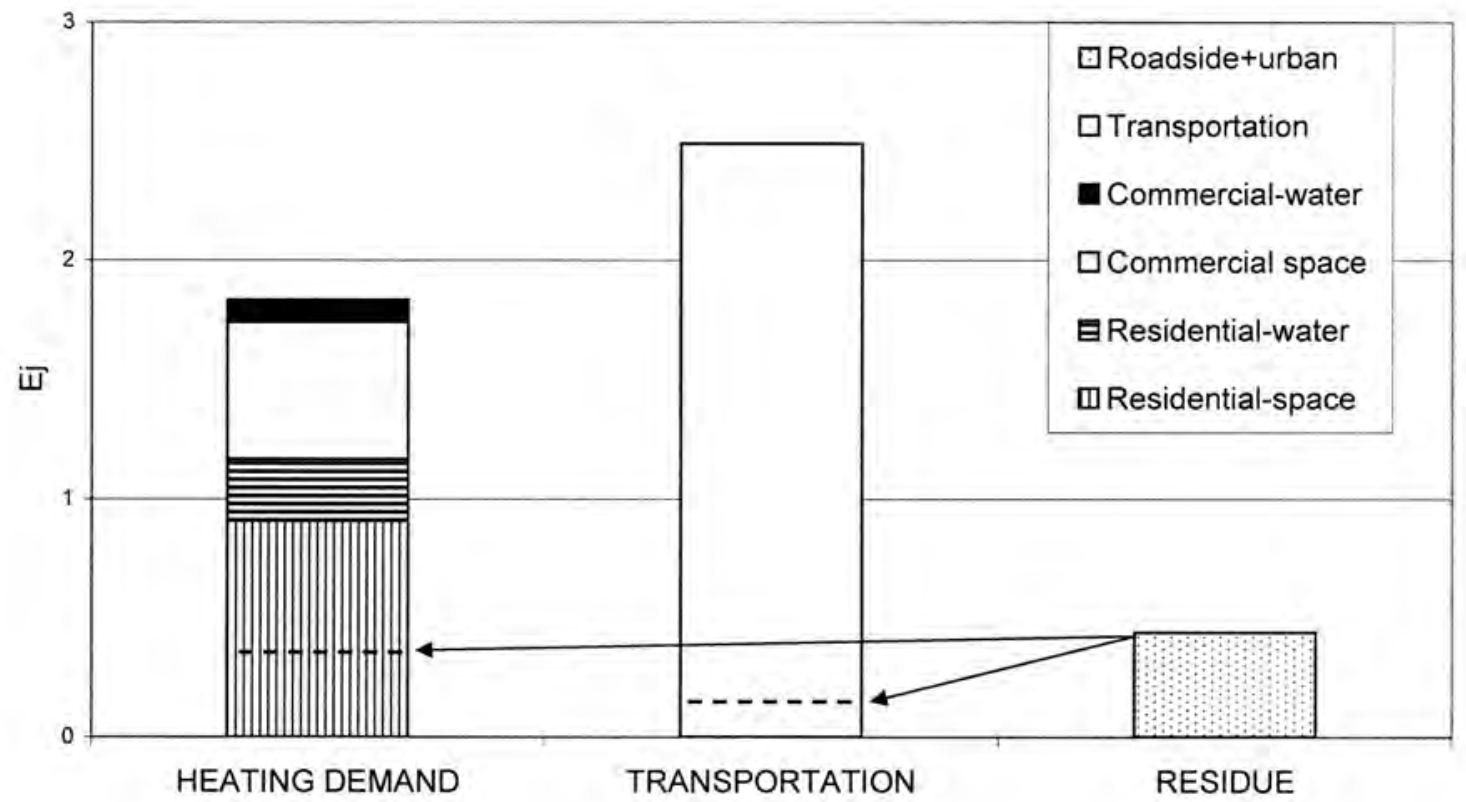

Fig. 3. Comparison between energy use in commercial and residential heating (space and water heating), energy used in transportation, and potential energy contained in total roadside harvest and urban forest residues (Ej). (data from Fig. 1 (Sidders et al. 2OO8) and Fig. 2 (OEE २०१०). Arrows and hatched lines indicate estimated contribution of residue energy to meet the demand based on today's technology.

generated from the combustion of cellulosic ethanol has an efficiency of $50 \%$, the efficiency of converting green wood into combined heat and power (CHP) is about 75\%, and the efficiency of producing heat from wood pellets is $80 \%$. These latter two technological pathways, because of their high effi- ciency, are currently considered to be the best options for biomass to meet our energy demands. Using the estimates by Sidders reported in Fig. 1, the direct combustion of wood residues not currently used by industry could contribute up to $24 \%$ of Canada's heating needs (Fig. 3), thereby reducing 
greenhouse gas (GHG) emissions or freeing up electricity for purposes other than heating. Nevertheless, most of the fossil fuel consumption in Canada is associated with the transport sector (Fig. 2 and Fig. 3). Life cycle analyses (LCA) have found, with the exception of a few studies, a net reduction in global warming emissions when biofuels are used to replace conventional diesel and gasoline (Cherubini 2010). However, current technologies for converting wood biomass to produce liquid fuels such as cellulosic ethanol show conversion efficiency in the range of $40 \%$ to $45 \%$ (Manomet Center for Conservation Sciences 2010). Therefore, while liquid fuels would contribute to meeting part of the national energy demand and could be of interest for environmental, economic and energy security aspects, their lower energy conversion efficiency would translate into a smaller benefit to meet energy demands and a smaller reduction in GHG emissions than heat production with efficient technologies such as efficient boilers or CHP.

\section{How Can Bioenergy from Forest Biomass Best Con- tribute to Reducing GHG Emissions?}

As described above, the technology that is used to convert wood into usable energy greatly affects the amount of energy that is made available as well as the benefits of using forest biomass to offset GHG emissions. Emissions generated biologically by harvesting and operationally during the harvesting, transport and processing of forest residues also affect the net GHG reduction potential of bioenergy, as well as the economic viability of projects. Life cycle analysis suggests an energy input-output ratio of 1:22 for wood burning (Pimentel and Pimentel 2008) when the energy used for cutting, collecting and transporting wood to a facility is taken into consideration, with transport accounting for most of this energy, and its associated $\mathrm{CO}_{2}$ emissions (Gaboury et al. 2009).

Finally, estimation of GHG reduction benefits of a bioenergy project is highly dependent on the time over which these benefits are calculated. Using forest biomass to replace fossil fuels does generate a reduction in net $\mathrm{CO}_{2}$ emissions over time but may initially increase emissions simply because biomass generates more $\mathrm{CO}_{2}$ per unit of energy produced than fossil fuel or because using forest biomass may cause a reduction in land C storage (Fargione et al. 2008). This concept, also called the carbon debt, may at first appear counterintuitive but can be illustrated by a simple example: the amount of heating oil that would generate an emission of $0.8 \mathrm{~T} \mathrm{CO}_{2}$ would provide the same heat as the use of an amount of wood pellets generating an emission of $1 \mathrm{~T} \mathrm{CO}_{2}$ (Manomet Center for Conservation Sciences 2010) because more energy per unit $\mathrm{C}$ is embedded in heating oil. Nevertheless, as C re-accumulates in the forest (and not in the fossil fuel pool), the net effect on atmospheric $\mathrm{C}$ of substituting biomass for fossil fuel will eventually become neutral and then positive. In this example, the use of $1 \mathrm{~T}$ equivalent $\mathrm{CO}_{2}$ of wood pellets would eventually result in a net reduction of $0.8 \mathrm{~T} \mathrm{CO}_{2}$ emissions into the atmosphere when replacing heating oil. It is important to note that wood energy is not carbon-neutral per se but its substitution of fossil energy does contribute to substantially reducing our contribution to GHG emissions. The time required for $\mathrm{CO}_{2}$ emissions from bioenergy production to drop below that of fossil fuel alternatives depends on several factors that we cannot cover in this paper. Nevertheless, it can be relatively short, especially when considering the use of log- ging residues which, if unharvested, would rapidly emit the $C$ they contain into the atmosphere. For example, the time required before the use of heat from harvest residue begins to have a lower net emission of $\mathrm{CO}_{2}$ than that of natural gas, a relatively efficient fuel, was estimated to be only four years for Finnish boreal forests (Repo et al. 2010).

\section{Conclusion}

Compared with other sources of feedstock for energy production, forest biomass requires small energy inputs in management and harvest operations per unit of embedded energy and therefore ranks very high in terms of energy efficiency (Tampier et al. 2005). Forest biomass offers an interesting and largely untapped potential, both for meeting a portion of Canada's energy requirements and for offsetting GHG emissions. Although Canada has a large forest landbase, it is clear that forest biomass cannot satisfy more than a small fraction of our current energy demands. It therefore behooves us to use this resource in the most $\mathrm{C}$-efficient manner possible. The greatest gains in offsetting fossil fuel GHG emissions with current bioenergy technologies will likely be made by using forest biomass for direct combustion for heating or for combined heat and power through community-based projects close to forest biomass sources.

\section{References}

Atlantic Provinces Economic Council. 2003. The New Brunswick forest industry: The potential economic impact of proposals to increase the wood supply. Available at http://www.gnb.ca/0078/ apec-e.pdf [Accessed Sept. 27, 2010].

Bauen, A., J. Woods and R. Hailes. 2004. Biopowerswitch! A biomass blueprint to meet $15 \%$ of OECD electricity demand by 2020 . WWF International and Aebiom. Available at http://assets.panda. org/downloads/biomassreportfinal.pdf [Accessed April 21, 2009].

Bradley, D. 2009. Canada report on bioenergy 2008. Environment Canada and IEA Bioenergy Task 40. Available at http://www.bioenergytrade.org/downloads/canadacountryreportjun2008.pdf.

Cherubini, F. 2010. GHG balances of bioenergy systems Overview of key steps in the production chain and methodological concerns. Ren. Energy 35: 1565-1573.

Dymond, C.C., B.D. Titus, G. Stinson and W.A. Kurz. 2010. Future quantities and spatial distribution of harvesting residue and dead wood from natural disturbances in Canada. For. Ecol. Manag. 260: $181-192$.

European Environment Agency. 2006. How much bioenergy can Europe produce without harming the environment? EEA Report No. 7/2006. Available at http://www.eea.europa.eu/publications/ eea_report_2006_7 [Accessed April 21, 2009].

FAO. 1998. Global fibre supply model. The Food and Agricultural Organization of the United Nations, Rome, Italy. Available at http://www.fao.org/docrep/006/x0105e/x0105e00.htm

[Accessed Sept. 27, 2010].

FAO. 2007. State of the world's forests 2007. The Food and Agriculture Organization of the United Nations, Rome, Italy. Available at http://www.fao.org/docrep/009/a0773e/a0773e00.HTM

Fargione, J., J. Hill, D. Tilman, S. Polasky and P. Hawthorne. 2008. Land clearing and the biofuel carbon debt. Science 319: 1235-1238. Gaboury, S., J.-F. Boucher, C. Villeneuve, D. Lord and R. Gagnon. 2009. Estimating the net carbon balance of boreal open woodland afforestation: A case-study in Québec's closed-crown boreal forest. For. Ecol. Manag. 257: 483-494.

Government of New Brunswick. 2008. Forest biomass harvesting policy. Available at http://www.gnb.ca/0078/policies/fmb0192008E .pdf [Accessed Sept. 27, 2010]. 
Grushecky, S.T., J. Wang and D.W. McGill. 2007. Influence of site characteristics and costs of extraction and trucking on logging residue utilization in southern West Virginia. For. Prod. J. 57: 63-67. Hesselink, T.P. 2010. Increasing pressures to use forest biomass: A conservation viewpoint. For. Chron. 86: 28-35.

Koistinen, A. and O. Äijälä. 2005. Energiapuun korjuu [In Finnish. Energy Wood Harvesting]. Tapio, Helsinki, Finland. 40 p.

Mabee, W.E., E.D.G. Fraser, P.N. McFarlane and J.N. Saddler. 2006. Canadian biomass reserves for biorefining. Appl. Biochem. Biotechnol. 129-132: 22-40.

Manomet Center for Conservation Sciences. 2010. Massachusetts Biomass Sustainability and Carbon Policy Study: Report to the Commonwealth of Massachusetts Department of Energy Resources. T. Walker (ed.). Natural Capital Initiative Report NCI-2010-03, Brunswick, ME.

[NRCan] Natural Resources Canada. 2006. Canada's energy outlook: The reference case 2006. Available at http://www.nrcanrncan.gc.ca/com/resoress/publications/peo/peo-eng.php. 2009. The State of Canada's Forests: Annual Report 2007. Canadian Forest Service, Ottawa.

[OEE] Office of Energy Efficiency, Natural Resources Canada. 2010. Energy use data handbook 1990 to 2007. http://www.oee. nrcan.gc.ca/corporate/statistics/ [Accessed July 10, 2010] data for year 2007.

Paquette, A. and C. Messier. 2010. The role of plantations in managing the world's forests in the Anthropocene. Front. Ecol. Environ. 8: 27-34.

Pimentel, D. and M.H. Pimentel. 2008. Food, Energy, and Society. $3^{\text {rd }}$ edition. CRC Press, Boca Raton, FL. 380 p.

Ralevic, P., J. Karau, C.T. Smith and J. Richardson. 2008. IEA Bioenergy Task 31 Country Report: Canada. Available at http://www.ieabioenergytask31.org/IEA_Bioenergy_Task_31/IEA\% 20 country\%20Report-\%20Canada\%202008-\%20Dec. \%20 2008\%20Final.pdf [Accessed Sept. 27, 2010].

Ralevic, P., M. Ryans and D. Cormier. 2010. Assessing forest biomass for bioenergy: operational challenges and cost considerations. For. Chron. 86: 43-50.
Repo, A., M. Tuomi and J. Liski. 2010. Indirect carbon dioxide emissions from producing bioenergy from forest harvest residues. Global Change Bioenergy, doi: 10.1111/j.1757-1707.2010.01065.x

Röser, D., A. Asikainen, I. Stupak and K. Pasanen. 2008. Forest energy resources and potentials. In D. Röser, A. Asikainen, K. Raulund-Rasmussen and I. Stupak (eds.). Sustainable use of forest biomass for energy. A synthesis with focus on the Baltic and Nordic Region. pp. 9-28. Springer, Dordrecht, The Netherlands.

Sidders D., B. Joss and T. Keddy. 2008. Natural Resources Canada (NRCan) - Canadian Wood Fibre Centre and Canadian Forest Service. Project TID8 25B GIS-Based Inventory and Analysis of Forestry and Agriculture Biomass: Biomass Inventory and Mapping Assessment Tool (BIMAT). Available at http://www4.agr.gc.ca/AAFCAAC/display-afficher.do?id=1226509218872\&lang=eng.

Skogsstyrelsen. 2008. Recommendations for extraction of forest residues and ash recycling. Directive 2-2008 [In Swedish]. 33 p.

Smeets, E.M.W. and A.P.C. Faaij. 2007. Bioenergy potentials from forestry in 2050. An assessment of the drivers that determine the potentials. Clim. Change 81: 353-390.

Tampier, M., D. Smith, E. Bibeau and P.A. Beauchemin. 2005. Identifying environmentally preferable uses for biomass resources. Stage 2 Report: Life-cycle emission reduction benefits of selected feedstock-to-product threads. Natural Resources Canada and National Research Council Canada. 132 p. [January 2005 update of original July 2004 report.] Available at http://www.cec.org/Storage/ 55/4771_Biomass-StageII-Final.pdf [Accessed Sept. 27, 2010].

Thiffault, E., D. Paré, S. Brais and B.D. Titus. 2010. Intensive biomass removals and site productivity in Canada: A review of relevant issues. For. Chron. 86: 36-42.

Titus, B.D., D.G. Maynard, C.C. Dymond, G. Stinson and W.A. Kurz. 2009. Wood energy: Protect local ecosystems. Science 324: 1389-1390.

Wood, S.M. and D.B. Layzell. 2003. A Canadian biomass inventory: Feedstocks for a bio-based economy. Final Report. BIOCAP Canada Foundation, Kingston, ON. 42 p. Available at http://www. agwest.sk.ca/bioproducts/documents/BIOCAP_Biomass_Inventory_000.pdf [Accessed Sept. 27, 2010]. 